\title{
THE IMPORTANCE OF THE FOREIGN CURRENCY CLAUSE IN FOREIGN BUSINESS TRANSACTIONS
}

\section{Vanja Ćosović}

PhD candidate, Singidunum University, Belgrade, Serbia

\begin{abstract}
:
The principal purpose of a foreign currency clause in economic and financial transactions is to preserve a real value of business operations from the moment of contract conclusion until their completion. There are three types of hedging instruments: monetary clause, index clause and sliding scale clause. The issue of foreign currency clause is much more complex when business operations are concluded with foreign partners due to different legal regulations and, in some cases, political systems. It becomes even more complex in case of long term and high value contracts. It could become especially complicated in case of cancelling a contract. Therefore, defining a currency clause as well as the means (and institutions), local and international for hedging is of utmost importance. It is also significant that the parties agree on competent courts and laws according to which disputes shall be settled. In this paper we will give examples from practice.
\end{abstract}

Keywords:

foreign currency clause, loan credit, change of circumstances, contract cancellation, caselaw
Correspondence:

Vanja Ćosović

e-mail:

\section{INTRODUCTION}

Risk free business operations in an era of globalization and more frequent crises, like the last one in 2008 which is not over yet, are not possible. However, the risk should be reduced to the least possible degree, which requires the individuals with outstanding academic credentials. Stipulation of the foreign currency clause is one of the possible hedging instruments against the potential business risks in overseas business transactions and in concluding the contracts in Serbia by pegging the monetary amount to foreign currency, which is allowed under Law on Foreign Currency Transactions (LFCT) (Article 2, paragraph 1, subparagraph 24 of the LFCT) and Law on Obligations (LO). Due to exceptional importance of the question of risk in all business fields, the International Organization for Standardization has, in ISO 9001 version for the year 2015, introduced requests for the introduction, application, maintenance and upgrading of the quality management system. Beside the said ISO standard, in the year 2009 a new ISO standard 31000:2009- risk management was established (ISO standard 31000:2009). This was the first international norm of global character in risk management in the world and implies the authority, resources and structure of risk management in an organization which makes possible the efficient risk management. The notion of quality is often linked to sophistication, elegance, sometimes luxury, and is not easily defined, but one thing is certain, quality is not an absolute value, but a relative one. (Ivanchevich, Lorenzi, Skinner and Crosby, 1994). The purpose of this paper is to explain in a nutshell the concept and types of risks, hedge instruments and, further, behaviour in the event of changed circumstances and the cases of rescission 
of contracts. In the end, a caselaw judicial precedent will be cited in relation to housing loans that were approved with currency clause pegged to the Swiss Franc.

\section{HEDGE CLAUSES}

\section{Monetary Clause}

Starting with the fact that in contemporary conditions the foundation of business comprises four freedoms: the free movement of goods, capital, services and labour, and that the business transactions are almost inconceivable without the line of credit extended to business organizations, banks or private individuals, this implies that the loan agreements must include the monetary clause. By honoring the monetary nominalism principle, when the subject-matter of the obligation is a specific amount of money, the debtor must pay that amount of monetary units in which the obligation is denominated, unless the law provides otherwise. If, however, the pecuniary obligation is denoted for disbursement in foreign currency or gold, its fulfilment may be demanded in home currency according to the exchange rate in force at the moment of performance of the obligation (Article 394-395 LO). This principle is in conformity with the good faith principle and the principle of equivalency of prestations, since in any case, the debtor who delays with performance of monetary obligation shall pay beside the principal amount also the legal rate of interest thereon, in conformity with the law (Article 277 LO) (Antić, 2014).

According to domestic legislation contracting in foreign exchange in the Republic is permitted, but any payments and collections made in relation to such contracts must be made in dinars (Article 34, paragraph 7 of the LFCT).This legal provision is intended to preserve the value of contracted business deals in the event of fundamental change of circumstances in the monetary sphere from the moment of contract formation until its performance.

Besides said, it should be taken into account that the mechanism of foreign currency conversion has been determined by caselaw of the Court of Justice of European Union (CJEU), which is of utmost importance for the global capital flow. From the example which follows it may be seen how the Russian ruble has lost ground in the course of one year in relation to US dollar, due to imposition of the sanctions against the Russian Federation.
Table 1. Fluctuation of the exchange rate of Ruble to US dollar in the period from 5.9.2017 to 5.9.2018.

\section{Sep 2017 00:00 UTC - 5 Sep 2018 15:07 UTC}

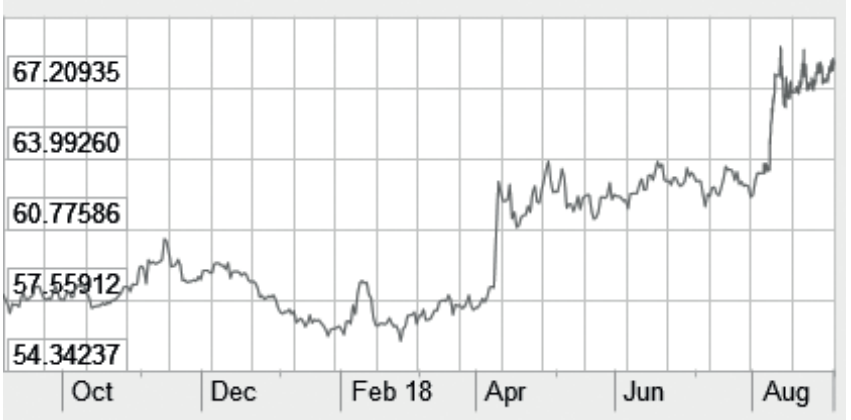

Source: https://www.X-rates.com/table/?from=USD\&amount=1

Highest inflation rate in the Twentieth century was recorded in Germany in the year 1923, when the monthly inflation rate was around $29.500 \%$, and the money was printed in 150 printing works by 2000 printing presses, while the monthly inflation rate in the Federal Republic of Yugoslavia in September 1993 was $743.2 \%$.

Beside the foreign currency clause, the fulfilment of pecuniary obligation may be demanded in relation to the value of gold since the gold clause is legally permitted, and the obligation shall be discharged in domestic currency according to the rate of exchange (price of gold) valid at the moment of fulfilment of the obligation (Article 395 LO).

\section{Indexation Clause}

Indexation Clause is classed into special type of commodity risk, the price risk. This risk is most often linked to three possible causes: first, if there are changes in previously established supply and demand ratio on the market for certain type of commodity (services) resulting in the correction of the stipulated price; second, if the price has changed due to new measures of monetary or fiscal authorities, and the third, if the buyer has additional requests not in conformity with contractual stipulations. In regard to the above mentioned occurrences which result in price deviation, it is of material importance to incorporate the legally permitted indexation clause in the contracts. By inserting the indexation clause a protection is afforded against the potential decline in the value of money (most often inflation or devaluation), which as a consequence has the correction of the price of goods, services and labour in the period from contract formation until its performance. The seller in such cases, out of conventional kindness in business, endeavours to meet the needs of the buyer, within certain limits. These limits 
within which the seller, without running the risk for his own business result, may fulfil the needs of the buyer, are set up to the level of common business risk (not-included risks-self-insurance) which as such, has already been included in the very calculation of the subject of the sales and purchase agreement. However, when such limit is reached or surpassed by the subsequent demands of the buyer, which constitutes new debit of commercial calculation, an adequate commercial solution should be found in the form of correction of contractual price for the subjectmatter of the sale and purchase agreement (Tešić, 1996).

Indexation clause may be stipulated only if for certain commmodity (services) there are Average Price Indices, that are periodically published by the competent government institutions (national Census Bureaus).

\section{Sliding Scale Clause}

As regards long-termy delivery of equipment of large value (plants, machinery, devices, turn-key construction contracts), there is a fully reliable hedge system against decline in value of such business deals, i.e. by inserting the so-called Price Adjustment Clause to the original contractual price stipulated in the sale and purchase agreement (Article 397.CO). The clause has the impact by applying the Sliding Scale Method (Tešić, 1989).

There are many sliding scale methods, but most often two of them are used in practice: mathematical method which consists of applying certain math formula that includes all the elements of the price structure and the descriptive method of the sliding scale. In the descriptive method one part of the price structure is subject to changes in prices (e.g. 70\% of the value of the agreed upon business deal, while the other part is set in fixed prices. In day-to-day business a combination of the descriptive method and mathematical formula is most often applied.

The application of the sliding scale method is based on the following principles:

- It equally protects the interests of both contracting parties;

- At the moment of contract formation, there must be an uncertainty in regard to forthcoming situation in the country where the construction site is located, as regards the price of material and workforce;

- Time of impact of variable factors of mathematical formula of the sliding scale should overlap with the time of actual incurring of the construction costs during the construction period;

- Sliding Scale Method may have an impact only within the agreed-upon period for dischage of assumed obligation;
- Sliding Scale Method, when applied, does not hedge against impediments in fulfilling the contractual obligations if one of the contracting parties, due to its own fault, absent the force majeure event beyond its control, has failed to perform in due time certain activity it had been obliged to do under the contract or according to ordinary course of business (Tešić, 1989).

Developed countries have special hedging instruments against commercial and non-commercial risks through specialized institutions which are in credit business of approving credit lines or are in export business insurance (Hermes in France, COFACE in France etc.) and so do the international financial institutions (MIGA, etc.).

\section{CHANGE IN CIRCUMSTANCES}

One of the basic tenets in obligation relations is the equality of the parties. This principle refers to all participants in obligatory relations. It has been proclaimed in Article 11 of the LO which reads as follows: „Parties to obligation relations shall be equal in terms of law“. This principle may be called, as it is oftentimes named, the principle of equality of the parties and equality of their wills (Đorđević and Stanković, 1987). The principle that the agreements must be kept is on the same footing with the above said principle, whenever that is possible. This principle known as „pacta sunt servanda“ is still valid today as the foundation of the certainty of legal transactions. It happens, however, that the circumstances under which the contract had been concluded changed in the meantime, so that the performance of the obligation would be too burdensome for one party or expose it to excessive losses. In such situation, it had been pointed out that a contracting party should be permitted to demand a modification of its contractual obligation and even ask for rescission of the contract. A prevailing view in present-day legal thought is that „Rebus sic stantibus" clause (Change in circumstances) should be treated as a legal remedy whose aim is to protect the principle of equivalency when such principle has been broken. (Đorđević and Stanković, 1987). In one judgment rendered in favor of a legal entity, Appellate Commercial Court confirmed the judgment of Belgrade Commercial Court, as the court of first instance, which rescinded the loan agreement with foreign (CHF) currency clause. That court judgment declared that the exchange rate of Swiss franc against dinar under the contract from 2007 until the end of 2016 had increased by $239 \%$, which was deemed to be a material change in circumstances. 


\section{RESCISSION OF A CONTRACT}

If after the formation of the contract there are new circumstances which make it more burdensome for one contracting party to discharge the obligation or if due to such conditions the purpose of the contract cannot be realized, all of the said in such degree that it is self-evident that the contract no longer suits the contracting parries, a party who has been affected by such circumstances may demand the rescission of the contract. Still, the contract will not be rescinded if the other party offers or agrees that the contract be equitably amended.

In the event of rescission, the court shall, at the request of the other party, impose a duty against the party requesting it, to compensate to the other party an equitable part of the loss sustained due to rescission (Article 133.LO).

An Obligation may be terminated due to impossibility of fulfilment, or performance. This has repercussions, mutatis mutandis, on the contract itself. As regards the contractual obligations, one can only speak about the supervening impossibility, after the formation of a valid contract, that is to say of the impossibility which has arosen subsequent to the formation of the contract. If the obligor has assumed an impossible obligation, it means that the other party cannot enforce such obligation, i.e. that between them there is no obligatory relation (Antić, 2014).

\section{CASELAW}

The most striking exampe in the application of the above mentioned clauses are the cases of granting the loans to individuals as well as businessmen and entrepreneurs for purchase of real property with the application of the currency clause pegging the domestic currency to Swiss franc. Legal basis for approving the foreign curency loan to residents is contained in Article 25 of the Law on Foreign Currency Transactions which reads as follows:, Banks may grant credits in foreign exchange to resident legal entities and entrepreneurs for the payment of imported goods and services from abroad“. „Banks may grant credits in foreign exchange to resident natural persons for the purchase of real estate in the country". This was the first time ever since the year 2006 that the granting of foreign currency loans has been permitted to natural persons for the purchase of real estate in Serbia and though it was legally possible to approve a loan in dinars with foreign currency clause since 2000, the banks did not act accordingly. The reason was very simple since the banks did not have sufficient deposits in Swiss francs to disburse loans in that currency. However, the banks have breached Article 1065 of the LO which reads as follows: „By a contract of credit the bank shall assume the obligation to place at the disposal of a beneficiary of the credit a specific amount of money, for a definite or indefinite period of time, and for specific purpose or without such purpose, while the beneficiary shall assume an obligation to pay to the bank the stipulated interest and repay the received amount of money, at the time and in the way determined by contract". Instead of offering private citizens Swiss francs, the banks have disbursed dinar counter-value according to the exchange rate valid on the date when the loan had been approved (granted), and the instalment plan was made in CHF. This means that contrary to Article 1065 of the LO, citizens are repaying the loan in foreign currency (which they have not received) instead in dinars (which they received). The "bait" for the borrowers was a lesser rate of interest and slower increase of $\mathrm{CHF}$ exchange rate, since the exchange rate of Euro had been increasing faster in the said period, although it did not happen that way in the end. In the course of the proceedings some law courts have determined that from the date of drawing down the loans in $\mathrm{CHF}$, until the date of expert witness testimony, the CHF exchange rate has increased by $129 \%$, and in the same time the exchange rate for euro has increased by $57 \%$. By such conduct of the banks one of the basic principles of the law of obligations has been violated- the principle of equality of contracting parties.

At the same time the Consumer Protection Act was also broken since the bank in pre-contractual phase did not advise the borrowers what would be the consequences of signing such a loan agreement and how much the borrower will have to pay for the purchased real property. At the same time Article 5 paragraph 1 subparagraph 1) of the Consumer Financial Protection Act was violated since one of its basic tenets reads as follows:" a right to an arms-length contract with provider of financial services."

After disputes lasting many years between private citizens and banks throughout Europe where also many thousands of Serbian citizens have filed their applications, the European Court of Human Rights (ECtHR) rendered on 20 September 2017 its judgment in favor of the debtor, case file C-186/16, (European Court of Justice 2017) referring to Council Directive 93/13 EEC on unfair terms in consumer contracts of 5 April 1953 (Council Directive 93/13 EEC). The reason to issue the proceedings was an application filed by the Appellate Court in Oradea, Romania. Encouraged by the said judgment of the ECJ, first judgments have also been rendered in the countries of the region (Western Balkans). In the beginning of January 2018, a Slovenian court annulled the loan agreement in Swiss francs for the purchase of real property since the person who took the loan had not been informed regarding the high risk of such foreign currency arrangement. It was one of the first judgments in Slovenia and by that court judgment the loan repayment instalments were 
decreased by $60 \%$ after the loan agreement had been annulled. Decisions in favor of bank clients were passed in France, Spain and other countries, while Hungary was the first country which solved the problem by conversion of Swiss francs into Hungarian forints. Appellate Court in Novi Sad confirmed in mid-april 2018 the judgment of Novi Sad High Court which rescinded a long-term housing loan agreement with indexation clause in Swiss francs. On 5.10.2017. the number of approved loans with foreign currency clause in euros was 87.619 , and with curency clause in Swiss francs 17.780 (Ćatić, 2017).

\section{CONCLUSION}

Following conclusions may be drawn from the above text:

1. In present-day business conditions, hedging instruments like protective clauses in the contracts entered either for overseas or home transactions are needed and consequently permitted by our legislation. From the international standars aspect, risks are the subject matter of ISO 90012015 standard and ISO 31000:2009 - risk management, which is of utmost importance for high quality business transactions of our business organizations;

2. Basic principles of the law of obligations cannot be subverted: the principle of equal value of prestations, principle of equality of contracting parties, principles of prohibition of abuse of dominant position, principle of prohibition of abuse of law etc. It may be concluded on the basis of this article that the banks have not adhered to said principles;

3. Banks in Serbia, when granting the loans in Swiss francs for the purchase of real property, instead of monetary nominalism accepted by Serbia like most of the European countries (France, Italy, Switzerland etc.) have applied the monetary valorism „imported“ from Austria and hence the loan was indexed in Swiss francs, disbursed in dinars and instalment plans were made in Swiss currency. This was in contravention of Article 1065 of the LO according to which the borrowers were obligated to pay the banks interest and instalments for granted loan amount in dinars, which they had received, instead to repay the loan in Swiss francs, which they had not received. Thereby the detrimental consequences were transferred to borrowers and in such measure that they could not meet their obligations-to repay timely the loans increased for interest thereon;
4. Since when approving the loans with Swiss francs foreign currency clause the banks have violated the right of the consumers to be informed, it should be expected that the domestic courts will proceed in compliance with the ECJ judgment.

\section{LITERATURE}

Antić, O. (2014). Obligaciono pravo. Beograd: Pravni fakultet. Ćatić, P. (2017). Valutna klauzula u ugovorima o kreditu između dva susreta pravnika Kopaoničke škole prirodnog prava. Pravni život broj 11/2107; pp. 432.

Vijeće evropske zajednice, Direktiva EEZ93/13 od 5.4. 1993, o nepoštenim uslovima u potrošačkim ugovorima.

Đorđević, Ž. S., Stanković, V.S. (1987). Obligaciono pravo, Opšti deo. Naučna knjiga, Beograd; pp 280-281.

Ivanchevich, J.M., Lorenzi, P., Skinner, S.J., \& Crosby, P.B. (1994). McGraw-Hill Education Management: Quality and Competitiveness.

International Organization for Standardization. ISO standard 31000:2009- risk management

Evropski sud pravde. (2017). Odluka Evropskog suda pravde od 20.9.2017. - presuda u postupku pod brojem C-186/16 - o nepoštenim uslovima u potrošačkim ugovorima.

International Organization for Standardization (2015). Sistem menadžmenta kvalitetom (ISO 9001:2015).

Tešić, M. (1989). Klauzula revizije cene u domaćim i međunarodnim ugovorima o građenju-Klizna skala. Savremena administracija, Beograd, pp 104-118.

Tešić, M. (1996). Spoljnotrgovinsko poslovanje. Savremena administracija, Beograd, pp.196.

Rates table. Available on: https://www.x-rates.com/table/ ?from=USD\&amount=1 accessed September 10, 2018.

Službeni glasnik RS, br. 62/06,31/11, 119/12, 139/14 and 30/18. Law on Foreign Currency Transactions.

Službeni list SFRJ, br. 29/78, 39/85, 57/89. Law on Obligations. Službeni list SRJ, br. 31/93. Law on Obligations.

Službeni list SCG, br. 1/2003-1. Law on Obligations.

Službeni glasnik RS, br. 36/11 and 139/14. Law on the Protection of Financial Service Consumers.

Službeni glasnik RS, br. 62/14, 6/16-et seq. Consumer Protection Act. 